\title{
KESEDIAAN MEMBAYAR (WILLINGNESS TO PAY) BERAS ORGANIK DI KABUPATEN BANYUMAS DAN FAKTOR YANG MEMPENGARUHINYA
}

\author{
Niken Hapsari Arimurti1), Kusmantoro Edy Sularso'2), dan Anny Hartati ${ }^{3}$ ) \\ 1) Program Studi Agribisnis, Fakultas Sains dan Teknologi, Universitas Peradaban \\ Jl. Raya Pagojengan Km. 3 Paguyangan Brebes Jawa Tengah, Indonesia \\ 2,3) Departemen Agribisnis, Fakultas Pertanian, Universitas Jenderal Soedirman \\ Jl. DR. Soeparno, Kec. Purwokerto Utara, Kabupaten Banyumas, Jawa Tengah, Indonesia \\ e-mail: 1)niken.arimurti@gmail.com
}

(Diterima 10 Desember 2019 / Revisi 22 Mei 2020 / Disetujui 29 Mei 2020)

\begin{abstract}
The objectives of this study are: (1) to identify the characteristics of organic rice consumers in Banyumas Regency, (2) to determine the maximum average price for organic rice that consumers in Banyumas Regency are willing to pay, and (3) to analyze and find out factors underlying the consumers' willingness to pay for organic rice. This research was conducted in Banyumas Regency by interviewing 68 respondents who were selected using the snowball sampling method. Data is analyzed using descriptive analysis, contingent valuation method (CVM), and logistic regression analysis. The study indicates that the characteristics of organic rice consumers who are willing to pay more for organic rice in Banyumas Regency are mostly aged 36 to 55 years, having an undergraduate degree, working as civil servants, and having an income level of $\mathrm{Rp} 3.000 .001$ to $\mathrm{Rp}$ 6.000.000 with 1-4 family members. The maximum price for organic rice that consumers in Banyumas Regency are willing to pay is Rp18.346 per kilogram. Factors underlying the willingness to pay for organic rice are income, length of consumption, and consumers' perception of organic rice quality.
\end{abstract}

Keywords: consumers, logistic regression, organic rice, willingness to pay

\begin{abstract}
ABSTRAK
Penelitian ini dilakukan untuk (1) mengetahui karakteristik konsumen beras organik, (2) menentukan berapa rata-rata harga maksimal beras organik yang bersedia dibayar oleh konsumen, (3) menganalisa faktor-faktor yang mempengaruhi kesediaan konsumen membayar beras organik di Kabupaten Banyumas. Penelitian dilaksanakan di Kabupaten Banyumas dengan menggunakan 68 responden yang dipilih dengan menggunakan snowball sampling. Metode analisis data menggunakan analisis deskriptif, contingent valuation method (CVM) dan analisis regresi logistik. Hasil penelitian menyatakan bahwa karakteristik konsumen beras organik yang bersedia membayar lebih beras organik di Kabupaten Banyumas didominasi oleh konsumen berusia 36 tahun hingga 55 tahun, dengan latar belakang pendidikan sarjana, bekerja sebagai pekerjaan pegawai negeri sipil, dengan tingkat pendapatan Rp 3.000.001 hingga Rp 6.000.000 dan memiliki jumlah anggota keluarga satu sampai dengan empat orang. Harga maksimal yang bersedia dibayarkan oleh konsumen beras organik di Kabupaten Banyumas adalah Rp 18.346 per kilogram. Faktor-faktor yang mempengaruhi kesediaan membayar beras organik secara signifikan adalah pendapatan, lama mengonsumsi dan persepsi konsumen terhadap kualitas beras organik.
\end{abstract}

Kata kunci: beras organik, kesediaan membayar, kosumen, regresi logistik

\section{PENDAHULUAN}

Kekhawatiran konsumen tentang masalah lingkungan dan kesehatan yang disebabkan oleh produk makanan menyebabkan peningkatan permintaan produk organik (Gil et al., 2000). Menurut Purwasasmita dan Sutaryat (2014) masyarakat mulai membeli beras organik, sebagai bentuk kepedulian terhadap pentingnya kesehatan dan kelestarian lingkungan. Indeks glikemik beras organik rendah sehingga sangat direkomendasikan untuk orang yang sakit diabetes. 
Beras organik merupakan hasil pertanian ramah lingkungan yang semakin diminati konsumen karena alasan kesehatan dan berpotensi untuk menjadi tren (Setiyadi et al., 2016). Perubahan gaya hidup sehat tidak hanya di kotakota besar namun terjadi di sebagian masyarakat daerah. Beras organik saat ini sudah banyak diperjualbelikan di Kabupaten Banyumas. Beras organik banyak dijual di ritel modern seperti Rita Mall, Rita Swalayan, Moro, Aroma, Cherry serta agen-agen yang langsung memasarkan beras organik dari petani organik yang ada di Kabupaten Banyumas.

Kesediaan konsumen mengonsumsi beras organik dipengaruhi oleh karakteristik konsumen. Hasil penelitian Setiyadi et al. (2016), Yuningsih (2016), dan Riana et al. (2019) menyatakan konsumen beras organik di dominasi oleh perempuan, menempuh pendidikan di perguruan tinggi, memiliki pekerjaan tetap dengan jumlah angota keluarga empat orang.

Mayoritas konsumen beras organik adalah orang-orang yang memiliki pendapatan lebih tinggi daripada konsumen produk non organik sebab produk organik harganya lebih mahal. Setiyadi et al. (2016) menyatakan beras organik dikonsumsi untuk pemenuhan kebutuhan kualitas makanan pokok dan juga bagian dari gaya hidup. Gaya hidup masyarakat kelas menengah mendorong volume dan pola konsumsi pangan, karena pada umumnya pendapatan mereka cukup besar sehingga menginginkan peningkatan kualitas dan kuantitas bahan pangan khususnya beras (Nasution, 2016).

Mahalnya beras organik menjadi salah satu factor yang menyebabkan konsumen lebih memilih mengonsumsi beras non organik (Sumarwan et al., 2013b). Rusma et al. (2011) menyatakan bahwa segmentasi pasar beras organik masih terbatas sehingga belum terlalu dikenal masyarakat. Pemasar menghadapi beberapa kendala untuk memasarkan beras organik seperti masih sedikitnya strategi dalam menentukan harga yang menarik perhatian konsumen seperti diskon harga dan masih terbatasnya jumlah agen serta distributor beras organik di daerah.

Hasil survei lapangan harga beras organik di Kabupaten Banyumas berkisar antara Rp
14.000 sampai dengan Rp 40.000 per kilogramnya. Variasi harga dipengaruhi oleh ada atau tidaknya label sertifikasi organik pada kemasan dan jenis varietas beras organik yang dijual. Di Kabupaten Banyumas terdapat dua macam beras organik yang dipasarkan yaitu beras organik yang sudah terdapat sertifikasi organik dan beras organik yang diproduksi oleh petani-petani organik yang ada di Banyumas yang sudah menerapkan sistem pertanian organik namun belum mendapat sertifikasi organik karena kendala biaya sertifikasi yang mahal.

Produsen harus memikirkan cara mengatur harga jual beras organik untuk membangkitkan minat konsumen, yang mengarah pada kesediaan untuk membayar produk (Setiyadi et al., 2016). Menurut Celona (2015) willingness to pay digunakan untuk mengetahui kemampuan konsumen untuk membayar dengan tujuan memperbaiki kondisi lingkungan. Konsep kesediaan membayar merupakan pengukuran harga maksimum yang bersedia dibayarkan oleh seseorang untuk memperoleh barang atau jasa. Pelaku, penggiat dan pemasar beras organik di Kabupaten Banyumas harus mengetahui nilai kesediaan membayar beras organik serta faktor-faktor yang mempengaruhinya.

Nilai kesediaan membayar (willingness to pay) beras organik di setiap daerah tentu berbeda karena perbedaan nilai daya beli yang dipengaruhi tingkat pendapatan, perbedaan karakteristik konsumen, dan jenis beras organik yang dijual. Riana et al. (2019) menyatakan nilai willingness to pay beras organik yang dijual di Gelael Signature Semarang untuk beras organik merk Hotel Kepala Super adalah Rp 33.900 per kilogram, Hotel Beras Susu Rp 41.354 per kilogram, Hotel Sugar Free adalah Rp 49.202 per kilogram, Hotel White Rice adalah Rp 42.075 per kilogram dan Holistic Rp 42.066 per kilogram. Nilai rata-rata maksimum kesediaan membayar beras organik di Kota Bogor sebesar Rp 20.000 per kilogramnya (Fathia, 2018), sedangkan nilai rata-rata maksimum beras organik di Pontianak sebesar Rp 26.120 per kilogram (Setiyadi et al., 2016). Nilai rataan willingness to pay beras pandan wangi organik di Bandung sebesar $\mathrm{Rp}$ 24.000 per kilogram (Yuningsih, 2016). 
Setiyadi et al. (2016) mengemukakan bahwa usia, harga beras organik, kemasan, pengeluaran dalam sebulan, harga beras non organik serta status perkawinan berpengaruh terhadap WTP Riana et al. (2019) menyatakan kesediaan membayar lebih beras organik dipengaruhi oleh pendapatan, harga dan merek beras organik. Fathia et al. (2018) menyatakan kesediaan konsumen membayar lebih secara signifikan dipengaruhi oleh usia, pengetahuan dan pendapatan.

Faktor lainnya yang mempengaruhi willingness to pay adalah kualitas dan keamanan pangan dari produk organik. Kualitas produk menjadi alasan konsumen mau membayar lebih mahal untuk memperoleh produk pangan organik (Krystallis \& Chryssohoidis, 2005). Selain karakteristik konsumen, persepsi dan pengetahuan konsumen mengenai beras organik juga berpengaruh terhadap kesediaan konsumen beras organik. Persepsi dapat dipengaruhi oleh lamanya konsumen mengkonsumsi beras organik serta manfaat yang sudah dirasakan oleh konsumen.

Kombinasi karakteristik produk dan harga akan mempengaruhi persepsi konsumen terhadap mutu. Secara signifikan, semakin banyak informasi yang diterima konsumen tentang karakteristik produk, mereka akan semakin sedikit menggunakan harga sebagai variabel mutu. Terdapat hubungan antara harga dan mutu, namun hal ini bukan sesuatu yang sederhana karena pada kondisi tertentu konsumen akan menganggap mutu dari harga yang tinggi, namun disisi lain harga yang tinggi juga akan menurunkan nilai yang dirasakan dari sebuah merek. Penentuan harga harus dilakukan secara hati-hati, sehingga perlu dilakukan penelitian guna meningkatkan harga sebagai sarana untuk meningkatkan penjualan (Mowen dan Minor, 2002).

Penelitian terdahulu mengenai kesediaan membayar beras organik lebih banyak dilakukan di kota-kota besar seperti Bogor, Bandung dan Pontianak. Saat ini belum ada informasi mengenai karakteristik konsumen, nilai kesediaan membayar lebih beras organik di daerah khususnya di Kabupaten Banyumas dimana terdapat dua macam beras organik yang dipasarkan yaitu beras organik yang sudah terdapat sertifikasi organik dan beras organik yang diproduksi oleh petanipetani organik yang ada di Banyumas yang sudah menerapkan sistem pertanian organik namun belum mendapat sertifikasi organik karena kendala biaya sertifikasi organik yang mahal, sehingga tujuan dari penelitian ini adalah untuk mengetahui karakteristik konsumen beras organik di Kabupaten Banyumas, berapa nilai rata-rata kesediaan membayar lebih beras organik dan faktor-faktor apa saja yang mempengaruhinya.

\section{METODE}

\section{LOKASI DAN WAKTU PENELITIAN}

Lokasi Penelitian ini adalah di Kabupaten Banyumas, karena di Kabupaten Banyumas ada pertanian organik dan banyak dijumpai toko dan agen yang menjual beras organik. Pengambilan data dilakukan pada Desember 2019 hingga Januari 2020 dengan metode survey.

\section{METODE PENGUMPULAN DATA}

Penelitian menggunakan data primer yang didapatkan langsung dari sasaran penelitian dengan wawancara langsung dan dengan melalui pemberian kuesioner kepada responden yang merupakan konsumen beras organik.

\section{METODE PENENTUAN RESPONDEN}

Konsumen beras organik di Kabupaten Banyumas sulit diperkirakan secara tepat karena tidak ada data ataupun catatan lengkap tentang populasi konsumen beras organik di Kabupaten Banyumas, sehingga pengambilan sampel melalui metode snowball sampling.

Pada penelitian ini menggunakan 68 responden. Peneliti mendapatkan informasi awal dari Dinas Pertanian dan Ketahanan Pangan Kabupaten Banyumas. Pihak Dinas memberikan beberapa rekomendasi petani organik dan konsumen beras organik. Setelah mendapatkan data, peneliti menghubungi beberapa responden yang memenuhi kriteria secara acak, kemudian meminta responden untuk merekomendasikan keluarga, teman, atau kerabat yang sesuai kriteria untuk menjadi responden pada penelitian ini. Orang yang dimaksud dihubungi oleh peneliti, kemudian peneliti memilih responden yang sesuai kriteria. Kriteria responden adalah konsumen yang pernah membeli dan mengonsumsi beras organik. Responden akan diwawancarai secara langsung dengan menggunakan kuesioner. 


\section{METODE ANALISIS DATA}

Analisis data yang digunakan pada penelitian ini yaitu:

\section{Analisis Deskriptif}

Karakteristik konsumen beras organik dideskripsikan dan digambarkan dengan Analisis Deskriptif dengan penyajian data statistik dalam bentuk tabel dan presentase.

\section{Contingent Valuation Method (CVM)}

Nilai rata-rata willingness to pay (WTP) yang bersedia dibayarkan oleh konsumen beras organik dihitung dengan menggunakan Analisis CVM. Menurut Fauzi (2004) tahapan analisis CVM yaitu :

1) Membuat pasar hipotesis

Pasar hipotesis menggambarkan ilustrasi mengenai gambaran suatu kejadian jika di masa mendatang terjadi perubahan lingkungan. Pada penelitian ini digambarkan pentingnya mengonsumsi beras organik.

2) Menentukan nilai lelang (bids)

Nilai tawaran diperoleh dengan melalui wawancara langsung dengan memberikan pertanyaan terbuka kepada responden mengenai berapa nilai yang bersedia dibayarkan untuk membeli beras organik dan responden memberikan jawaban langsung jumlah nilai maksimal yang bersedia dibayarkan untuk mendapatkan beras organik, namun tetap dalam perhatian enumerator.

3) Menghitung rata-rata WTP

Nilai kesediaan membayar beras organik dihitung dengan persamaan berikut :

$$
E W T P=\sum_{i=1}^{n} W_{i}(P f i)
$$

Keterangan :

$$
\begin{aligned}
\text { EWTP }= & \text { Dugaan rataan WTP }(\mathrm{Rp} / \mathrm{kg}) \\
\mathrm{Wi}= & \text { Nilai WTP ke- } \mathrm{i} \\
\mathrm{Pfi}= & \text { Nilai relative responden ke-i } \\
\mathrm{i} \quad & \text { Responden ke- } \mathrm{i} \text { yang bersedia } \\
& \text { membayar beras organik }
\end{aligned}
$$

4) Mengestimasi kurva WTP

Estimasi kurva diperoleh dengan mengagregasikan Nilai WTP dengan beberapa variabel bebas menggunakan persamaan :

$$
W T P=f\left(X_{1} \ldots \ldots \ldots \ldots X_{n}\right)
$$

5) Agregasi data total WTP

Agregasi data total WTP diperoleh dari nilai rata-rata WTP yang dikonversikan terhadap populasi. Perhitungan total WTP menggunakan persamaan sebagai berikut :

$$
\text { TWTP }=\text { EWTP } \times \text { P }
$$

Keterangan :

$$
\begin{aligned}
\mathrm{TWTP}= & \text { Total Willingness to pay }(\mathrm{Rp}) \\
\mathrm{EWTPi}= & \text { Rataan nilai Willingness to pay } \\
& \text { Responden ke } \mathrm{i}(\mathrm{Rp} / \mathrm{kg}) \\
\mathrm{P} \quad= & \text { Populasi (orang) }
\end{aligned}
$$

\section{Regresi Logistik}

Penelitian ini menggunakan persamaan berikut :

$$
\begin{aligned}
\ln \left[\frac{p}{1-p}\right]= & \beta_{0}+\beta_{1} \mathrm{X}_{1}+\beta_{2} \mathrm{X}_{2}+\beta_{3} \mathrm{X}_{3}+\beta_{4} \mathrm{X}_{4}+ \\
& \beta_{5} \mathrm{X}_{5}+\beta_{6} \mathrm{X}_{6}+\beta_{7} \mathrm{X}_{7}+\beta_{8} \mathrm{X}_{8}+\mathrm{e}
\end{aligned}
$$

Keterangan :

$\mathrm{p}$ = Kesediaan konsumen membayar beras organic (ya/tidak)

$\beta_{0}=$ Konstanta regresi atau Intersep

$\beta_{1}=$ Koefisien regresi usia

$\beta_{2}=$ Koefisien regresi pendidikan

$\beta_{3}=$ Koefisien regresi pekerjaan

$\beta_{4}=$ Koefisien regresi pendapatan

$\beta_{5}=$ Koefisien regresi jumlah anggota keluarga

$\beta_{6}=$ Koefisien regresi lama mengonsumsi

$\beta_{7}=$ Koefisien regresi jumlah konsumsi

$\beta_{8}=$ Koefisien regresi kualitas beras organik.

$\mathrm{X}_{1}=$ Usia (tahun)

$\mathrm{X}_{2}=$ Pendidikan $((1=\mathrm{SD}, 2=\mathrm{SMP}, \quad 3=\mathrm{SMA}$, 4=Diploma, 5=Sarjana)

$\mathrm{X}_{3}=$ Pekerjaan $(1=$ pegawai swasta, $2=$ pegawai negeri, $3=$ wirausaha $4=i b u$ rumah tangga)

$\mathrm{X}_{4}=$ Pendapatan (Rp/bulan)

$\mathrm{X}_{5}=$ Jumlah anggota keluarga (orang)

$\mathrm{X}_{6}=$ Lama mengonsumsi $(1=0-12$ bulan, $2=13$ 24 bulan, $3=25-36$ bulan, $4=37-48$ bulan, $5=>48$ bulan)

$\mathrm{X}_{7}=$ Jumlah konsumsi ( $\mathrm{kg} /$ bulan)

$\mathrm{X}_{8}=$ Persepsi kualitas beras organik ( $0=$ kualitas rendah, $1=$ kualitas tinggi)

Pengujian parameter menggunakan Uji Kesesuaian Model (Goodness of Fit) dengan Uji Hosmer dan Lemeshow's untuk mengevaluasi sesuai tidaknya model dengan data, Uji Statistik G 
atau Likelihood Ratio Test untuk mengetahui pengaruh variabel bebas terhadap variabel terikat secara serempak di dalam model regresi logistic dan untuk mengetahui pengaruh variabel bebas terhadap variabel terikat secara parsial menggunakan Uji Wald.

Apabila pengujian parameter model telah dilakukan, langkah berikutnya yaitu melakukan interpretasi model dengan menggunakan Koefisien Determinasi untuk melihat berapa besar nilai variabel-variabel bebas mempengaruhi nilai variabel terikat, dan Odds Ratio yang dinyatakan dalam exp $(\beta)$ untuk menyatakan kecenderungan pengaruh observasi dengan kategori $\mathrm{Xi}=1$ adalah berapa kali lipat jika dibandingkan dengan observasi dengan kategori $\mathrm{Xi}=0$.

Hipotesis operasional dalam penelitian ini yaitu:

1. Usia berpengaruh positif dan signifikan pada kesediaan membayar beras organik. Artinya semakin tua usia konsumen kecenderungan membayar lebih beras organik akan semakin besar, dengan bertambahnya usia membuat konsumen lebih peduli terhadap kesehatan.

2. Pendidikan berpengaruh positif dan signifikan pada kesediaan membayar beras organik, yang berarti makin tinggi tingkat pendidikan akan semakin meningkatkan kecenderungan kesediaan membayar beras organik. Hal ini disebabkan konsumen yang tingkat pendidikannya menengah hingga tinggi lebih mempunyai kesadaran dan pengetahuan tentang pencemaran produk pangan dan lingkungan serta manfaat produk organik dibanding konsumen yang berpendidikan dasar.

3. Pekerjaan berpengaruh positif dan signifikan pada kesediaan membayar beras organik. Artinya konsumen yang mempunyai pekerjaan tetap memiliki kecenderungan kesediaan membayar beras organik. Hal ini dikarenakan responden dengan status pegawai memiliki penghasilan yang tetap setiap bulannya sehingga anggaran konsumsi sudah diatur tiap bulannya.

4. Pendapatan berpengaruh positif dan signifikan terhadap kesediaan membayar beras organik, yang berarti semakin tinggi jumlah pendapatan konsumen akan semakin meningkatkan kecenderungan kesediaan membayar beras organik karena beras organik harganya relatif lebih mahal dibanding dengan beras non organik. Konsumen yang memiliki pendapatan yang tinggi cenderung untuk mengonsumsi produk yang lebih berkualitas.

5. Jumlah anggota keluarga berpengaruh negatif dan signifikan terhadap kesediaan membayar beras organik, yang berarti makin banyak anggota keluarga akan makin menurunkan kecenderungan kesediaan membayarnya, karena makin banyak jumlah anggota keluarga akan makin meningkatkan pengeluaran keluarganya.

6. Lama konsumsi beras organik berpengaruh positif dan signifikan pada kesediaan membayar beras organik. Artinya lama mengonsumsi beras organik akan semakin meningkatkan kecenderungan kesediaan membayar beras organik. Lama mengkonsumsi menunjukkan tingkat kepercayaan terhadap beras organik (Sulistyana et al, 2014).

7. Jumlah konsumsi beras organik berpengaruh negatif dan signifikan terhadap kesediaan membayar beras organik, yang berarti bahwa kenaikan jumlah konsumsi akan menurunkan kecenderungan kesediaan membayar beras organik

8. Persepsi konsumen terhadap kualitas beras organik berpengaruh positif dan signifikan terhadap kesediaan membayar beras organik. Artinya semakin baik persepsi konsumen terhadap kualitas beras organik akan semakin meningkatkan kecenderungan kesediaan membayar beras organik. Konsumen merasa puas apabila produk yang digunakan memiliki kualitas yang baik.

\section{HASIL DAN PEMBAHASAN}

\section{KARAKTERISTIK KONSUMEN BERAS ORGANIK DI KABUPATEN BANYUMAS}

Penelitian ini melibatkan 68 responden yang merupakan konsumen beras organik baik yang telah mengonsumsi beras organik secara rutin maupun tidak. Sebanyak 50 responden atau 73,53 persen responden bersedia membayar lebih beras organik untuk mendapatkan manfaatnya, sedangkan sebanyak 18 responden atau 26,47 persen responden tidak bersedia membayar lebih beras organik. Karakteristik responden berdasar- 
kan usia, pendidikan, pekerjaan, pendapatan per bulan, dan jumlah anggota keluarga adalah sebagai berikut:

1. Usia

Usia merupakan faktor penting karena dapat menggambarkan pola pikir dan kematangan seseorang dalam mengambil keputusan. Kebutuhan konsumen berbeda sesuai dengan usianya, sehingga usia mempengaruhi seseorang dalam memutuskan untuk membeli atau mengonsumsi barang dan jasa. Klasifikasi usia dalam penelitian ini dibagi menjadi enam kelompok berdasarkan pada klasifikasi usia dari Departemen Kesehatan Republik Indonesia tahun 2009 yang meliputi masa remaja akhir yaitu usia 17 tahun sampai dengan 25 tahun, masa dewasa awal yaitu usia 26 tahun hingga 35 tahun, masa dewasa akhir usia 36 tahun hingga 45 tahun, masa lanjut usia awal yaitu 46 tahun hingga 55 tahun, masa lanjut usia akhir yaitu 56 tahun hingga 65 tahun dan masa manusia lanjut usia yaitu untuk usia di atas 65 tahun. Sebaran responden berdasarkan kelompok usia dijelaskan pada Tabel 1.

Sebagian besar konsumen beras organik berada pada kelompok usia dewasa akhir, selanjutnya diikuti kelompok usia lansia awal. Berdasarkan data pada Tabel 1 disimpulkan bahwa konsumen yang bersedia membayar lebih beras organik adalah usia 36 tahun hingga 45 tahun sebesar 27,94 persen diikuti usia 46 tahun hingga 55 tahun sebesar 26,47 persen, sehingga berdasarkan segmentasi usia, produsen maupun pemasar beras organik di Kabupaten Banyumas dapat mengkhususkan pada usia tersebut. Responden pada usia 36 sampai dengan 55 tahun ini pada umumnya sudah menikah dan memiliki keluarga serta memiliki pendapatan sendiri sehingga mereka bersedia membayar beras organik sesuai dengan tingkat kemampuannya. Konsumen pada usia 36-55 tahun cenderung selektif memilih konsumsi pangan yang lebih sehat untuk diri sendiri dan keluarganya. Hal tersebut sedikit berbeda dengan pendapat Riana et al. (2019) yang menjelaskan bahwa karakteristik konsumen yang bersedia membayar lebih beras organik di Semarang didominasi oleh usia 31 sampai dengan 40 tahun.

\section{Pendidikan}

Sumarwan et al. (2013b) mengemukakan bahwa tingkat pendidikan dapat mempengaruhi seseorang dalam pengenalan kebutuhan dan keputusan pembelian. Pada penelitian ini karakteristik responden menurut tingkat pendidikannya terbagi lima kelompok yaitu tingkat pendidikan SD, SMP, SMA, Diploma serta Sarjana. Sebaran responden diklasifikasikan dari tingkat pendidikan dijelaskan Tabel 2.

Tabel 1. Sebaran Responden Berdasarkan Usia

\begin{tabular}{ccccc}
\hline \multirow{2}{*}{ Usia } & \multicolumn{2}{c}{ Bersedia } & \multicolumn{2}{c}{ Tidak Bersedia } \\
\cline { 2 - 5 } & Jumlah Responden (orang) & Persentase (\%) & Jumlah Responden (orang) & Persentase (\%) \\
\hline 17 - 25 tahun & 2 & 2,94 & 1 & 1,47 \\
$26-35$ tahun & 4 & 5,88 & 7 & 10,29 \\
$36-45$ tahun & 19 & 27,94 & 6 & 8,82 \\
$46-55$ tahun & 18 & 26,47 & 2 & 2,94 \\
$56-65$ tahun & 6 & 8,82 & 1 & 1,47 \\
$>65$ tahun & 1 & 1,47 & 1 & 1,47 \\
\hline Total & $\mathbf{5 0}$ & $\mathbf{7 3 , 5}$ & $\mathbf{1 8}$ & $\mathbf{2 6 , 4 7}$ \\
\hline
\end{tabular}

Tabel 2. Sebaran Responden Berdasarkan Pendidikan

\begin{tabular}{lcccr}
\hline \multirow{2}{*}{ Pendidikan } & \multicolumn{2}{c}{ Bersedia } & \multicolumn{2}{c}{ Tidak Bersedia } \\
\cline { 2 - 5 } & $\begin{array}{c}\text { Jumlah Responden } \\
\text { (orang) }\end{array}$ & $\begin{array}{c}\text { Persentase } \\
\mathbf{( \% )}\end{array}$ & $\begin{array}{c}\text { Jumlah Responden } \\
\text { (orang) }\end{array}$ & $\begin{array}{c}\text { Persentase } \\
\text { (\%) }\end{array}$ \\
\hline SD & 0 & 0 & 1 & 1,47 \\
SMP & 2 & 2,94 & 0 & 0 \\
SMA & 9 & 13,24 & 1 & 1,47 \\
Diploma & 5 & 7,35 & 4 & 5,88 \\
Sarjana & 34 & 50 & 12 & 17,65 \\
\hline \multicolumn{1}{c}{ Total } & $\mathbf{5 0}$ & $\mathbf{7 3 , 5 3}$ & $\mathbf{1 8}$ & $\mathbf{2 6 , 4 7}$ \\
\hline Sumber: Analisis Data Primer, 2020 & & &
\end{tabular}




\section{Pekerjaan}

Pekerjaan seseorang akan mempengaruhi pola konsumsinya (Sumarwan et al., 2013a). Penelitian ini mengategorikan tingkat pekerjaan responden menjadi empat yaitu pegawai swasta, pegawai negeri sipil (PNS), wirausaha dan ibu rumah tangga. Sebaran responden berdasarkan pekerjaan dijelaskan pada Tabel 3.

Hasil penelitian menunjukkan bahwa pekerjaan responden yang paling banyak adalah Pegawai Negeri Sipil (PNS). Apabila dilihat dari kesediaan membayar beras organik, pekerjaan sebagai PNS memiliki kecenderungan yang paling besar untuk bersedia membayar beras organik, karena beberapa petani beras organik di Kabupaten Banyumas merupakan petani binaan dari Dinas Pertanian dan Ketahanan Pangan Kabupaten Banyumas dan Pihak Dinas membantu pemasaran hasil pertanian organik kepada pegawai di sekitar wilayah kerjanya. Selain itu, responden yang bekerja sebagai PNS memiliki penghasilan yang stabil sehingga mampu untuk memenuhi kebutuhan pangan yang berkualitas. Hasil penelitian ini sesuai dengan pendapat Hanis et al. (2012) yang mengemukakan 68,3 persen konsumen beras organik bekerja di sektor pemerintah.

\section{Pendapatan}

Pendapatan konsumen merupakan indikator pengeluaran keluarga tiap bulan. Tingkat pendapatan yang makin besar menunjukan makin besar tingkat pengeluaran untuk kebutuhannya. Sebaran responden berdasarkan tingkat pendapatan dijelaskan pada Tabel 4.

Hasil penelitian menunjukkan bahwa mayoritas responden beras organik berpenghasilan antara Rp 3.000.001 hingga Rp 6.000.000. Pada tingkat pendapatan tersebut konsumen sudah mulai memperhatikan kualitas makanan yang dikonsumsinya. Hal tersebut sesuai dengan pendapat Riana et al. (2019) yang mengemukakan bahwa Sebagian besar konsumen beras organik di Semarang tingkat pendapatan per bulannya Rp 3.000.000 hingga Rp 5.999.999. Data pada Tabel 4. menjelaskan bahwa tingkat pendapatan yang semakin tinggi memiliki kecenderungan konsumen tidak bersedia membayar beras organik semakin rendah. Hal ini berarti konsumen yang memiliki pendapatan yang tinggi, memiliki tingkat kesediaan membayar beras organik yang tinggi pula.

5. Jumlah Anggota Keluarga

Sebaran responden dilihat dari jumlah anggota keluarganya dibagi menjadi tiga kategori

Tabel 3. Sebaran Responden Berdasarkan Pekerjaan

\begin{tabular}{lcccc}
\hline \multirow{2}{*}{ Pekerjaan } & \multicolumn{2}{c}{ Bersedia } & \multicolumn{2}{c}{ Tidak Bersedia } \\
\cline { 2 - 5 } & $\begin{array}{c}\text { Jumlah Responden } \\
\text { (orang) }\end{array}$ & $\begin{array}{c}\text { Persentase } \\
\text { (\%) }\end{array}$ & $\begin{array}{c}\text { Jumlah Responden } \\
\text { (orang) }\end{array}$ \\
\hline Pegawai Swasta & 8 & 11,76 & 6 & 3 \\
PNS & 28 & 41,18 & 3,82 & 4,41 \\
Wirausaha & 12 & 17,65 & 2,94 & 7 \\
Ibu Rumah Tangga & 2 & 2,94 & $\mathbf{1 0}$ & $\mathbf{1 8}$ \\
\hline \multicolumn{1}{c}{ Total } & $\mathbf{5 0}$ & $\mathbf{7 3 , 5 3}$ & $\mathbf{2 6 , 4 7}$ \\
\hline
\end{tabular}

Sumber : Analisis Data Primer, 2020

Tabel 4. Sebaran Responden Berdasarkan Pendapatan

\begin{tabular}{ccccc}
\hline \multirow{2}{*}{\begin{tabular}{c} 
Pendapatan (Rp) \\
\cline { 2 - 5 }
\end{tabular}} & $\begin{array}{c}\text { Bersedia } \\
\text { Jumlah Responden } \\
\text { (orang) }\end{array}$ & $\begin{array}{c}\text { Persentase } \\
\text { (\%) }\end{array}$ & $\begin{array}{c}\text { Jumlah Responden } \\
\text { (orang) }\end{array}$ & $\begin{array}{c}\text { Persentase } \\
\text { (\%) }\end{array}$ \\
\hline $0-3.000 .000$ & 8 & 11,76 & 8 & 11,76 \\
$3.000 .001-6.000 .000$ & 17 & 25 & 8 & 11,76 \\
$6.000 .001-9.000 .000$ & 13 & 19,12 & 1 & 1,47 \\
$9.000 .001-12.000 .000$ & 7 & 10,29 & 0 & 1,47 \\
$>12.000 .000$ & 5 & 7,35 & $\mathbf{1 8}$ & $\mathbf{1 8}$ \\
\hline Total & $\mathbf{5 0}$ & $\mathbf{7 3 , 5 3}$ & $\mathbf{2 6 , 4 7}$ \\
\hline
\end{tabular}

Sumber : Analisis Data Primer, 2020 
yaitu keluarga kecil, keluarga sedang dan keluarga besar yang ditunjukkan pada Tabel 5 .

Berdasarkan Tabel 5 mayoritas jumlah anggota keluarga responden adalah keluarga kecil (satu sampai dengan empat orang). Hal tersebut menunjukkan bahwa makin sedikit jumlah anggota keluarga maka akan memiliki kemampuan yang lebih besar untuk menyejahterakan anggota keluarganya. Karakteristik jumlah anggota keluarga konsumen beras organik di daerah maupun di kota besar tidak terlalu berbeda. Konsumen beras organik di Semarang didominasi oleh keluarga kecil yang memiliki jumlah anggota keluarga empat orang (Riana et al., 2019).

\section{ANALISIS KESEDIAAN MEMBAYAR (WILLINGNESS TO PAY) BERAS ORGANIK DI KABUPATEN BANYUMAS.}

Willingness to pay atau kesediaan membayar lebih beras organik merupakan nilai maksimal yang bersedia dikorbankan oleh seseorang untuk mendapatkan manfaat dari beras organik. Analisis kesediaan membayar beras organic pada penelitian ini menggunakan pendekatan contingent valuation method (CMV) dengan langkahlangkah berikut :

1. Membangun Pasar Hipotesis

Pasar hipotesis menggambarkan ilustrasi mengenai gambaran suatu kejadian jika di masa mendatang terjadi perubahan lingkungan. Pada penelitian ini digambarkan pentingnya mengonsumsi beras organik. Informasi dalam bentuk deskripsi informasi produk disajikan dalam kuesioner.

Pasar hipotesis yang dibentuk pada penelitian ini yaitu "Beras organik adalah salah satu hasil pertanian organik yang saat ini banyak diminati masyarakat. Harga beras organik lebih mahal daripada beras non organik karena memberikan manfaat tambahan bagi kesehatan konsumen yaitu konsumen akan terhindar dari penyakit degeneratif yang disebabkan pestisida dan pupuk kimia. Selain itu, konsumen yang mengonsumsi beras organik berkontribusi dalam upaya pelestarian lingkungan." setelah informasi diberikan, konsumen diberikan pertanyaan apakah konsumen bersedia membayar lebih dari harga aktual beras organik untuk mendapatkan manfaat tambahan yang telah dijelaskan. Hasilnya dapat dilihat pada Gambar 1.

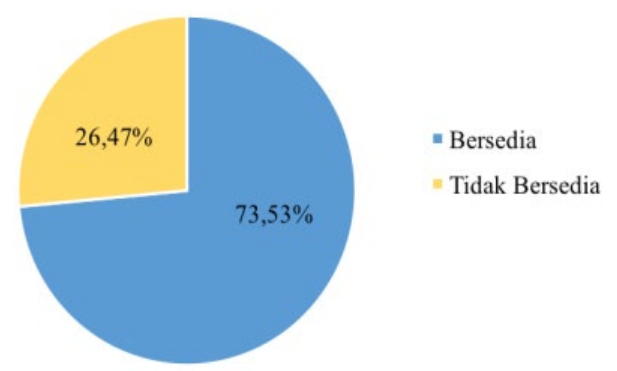

\section{Gambar 1. Sebaran Kesediaan Membayar Beras Organik}

Gambar 1 menjelaskan bahwa mayoritas konsumen bersedia membayar lebih beras organik untuk mendapatkan manfaat dari beras organik. Konsumen yang bersedia membayar lebih beras organik berpendapat bahwa manfaat yang dirasakan sebanding dengan harga beras organik, beberapa konsumen mendapatkan saran dari dokter agar mengonsumsi beras organik karena menderita suatu penyakit. Alasan lainnya yaitu karena rasa beras organik lebih enak dibandingkan dengan non organik, nasi yang dihasilkan dari beras organik lebih tahan lama dan lebih mengenyangkan sehingga kebutuhan akan beras organik lebih sedikit daripada ketika mengonsumsi beras non organik. Hasil tersebut mengkonfirmasi pendapat Purwasasmita dan Sutaryat (2014) yang menjelaskan bahwa kuantitas konsumsi beras lebih hemat.

Tabel 5. Sebaran Responden Berdasarkan Jumlah Anggota Keluarga

\begin{tabular}{lcccc}
\hline & \multicolumn{2}{c}{ Bersedia } & \multicolumn{2}{c}{ Tidak Bersedia } \\
\cline { 2 - 5 } Jumlah Anggota Keluarga & $\begin{array}{c}\text { Jumlah Responden } \\
\text { (orang) }\end{array}$ & $\begin{array}{c}\text { Persentase } \\
\text { (\%) }\end{array}$ & $\begin{array}{c}\text { Jumlah Responden } \\
\text { (orang) }\end{array}$ & $\begin{array}{c}\text { Persentase } \\
\text { (\%) }\end{array}$ \\
\hline Keluarga Kecil (1-4 orang) & 27 & $39,71 \%$ & 15 & $22,06 \%$ \\
Keluarga Sedang (5-6 orang) & 22 & $32,35 \%$ & 2 & 1 \\
Keluarga Besar ( $\geq 7$ orang) & 1 & $1,47 \%$ & $\mathbf{1 8}$ & $1,47 \%$ \\
\hline Total & $\mathbf{5 0}$ & $\mathbf{7 4 \%}$ & $\mathbf{2 6 \%}$ \\
\hline
\end{tabular}

Sumber : Analisis Data Primer, 2020 
Konsumen yang tidak bersedia membayar lebih beras organik mengemukakan alasannya yaitu karena sudah puas dengan beras non organik yang dikonsumsi selama ini, mereka belum bisa membedakan rasa beras organik dan beras non organik, dan belum merasakan manfaatnya, selain itu beberapa konsumen berpendapat bahwa harga beras organik terlalu mahal dan tidak sesuai pendapatan rumah tangganya. Selama ini membeli beras organik tidak secara rutin hanya beberapa kali mencoba ketika ada yang menawarkan beras organik. Mereka berharap agar harga beras organik tidak jauh berbeda dengan beras non organik agar semakin banyak masyarakat yang dapat menikmati bahan makanan pokok yang berkualitas dan bermanfaat bagi kesehatan.

\section{Nilai Lelang (Bids)}

Nilai lelang digunakan untuk mengetahui nilai willingness to pay (WTP) beras organik, responden diberikan pertanyaan nilai tawaran yang diperoleh melalui wawancara langsung menggunakan kuesioner dengan pertanyaan terbuka mengenai jumlah nilai yang bersedia dibayarkan untuk memperoleh beras organik dan responden memberikan jawaban secara langsung berapa nilai maksimal yang bersedia dibayarkan untuk mendapatkan beras organik. Distribusi nilai (harga) yang bersedia dibayarkan responden terhadap beras organik di Kabupaten Banyumas ditunjukan pada Tabel 6 .

Tabel 6. Distribusi Nilai WTP

\begin{tabular}{lrrrr}
\hline $\begin{array}{c}\text { Nilai WTP } \\
\text { (Rp/kg) }\end{array}$ & $\begin{array}{c}\text { Jumlah } \\
\text { Res- } \\
\text { ponden } \\
\text { (orang) }\end{array}$ & $\begin{array}{c}\text { Fre- } \\
\text { kuensi } \\
\text { Relatif } \\
\text { (Pfi) }\end{array}$ & $\begin{array}{c}\text { Mean WTP } \\
\text { (Rp) }\end{array}$ & $\begin{array}{c}\text { Total WTP } \\
\text { (Rp) }\end{array}$ \\
\hline 12.000 & 3 & 0,04 & 529 & 36.000 \\
13.000 & 4 & 0,06 & 765 & 52.000 \\
14.000 & 2 & 0,03 & 412 & 28.000 \\
15.000 & 11 & 0,16 & 2.426 & 165.000 \\
15.500 & 1 & 0,01 & 228 & 15.500 \\
16.000 & 2 & 0,03 & 471 & 32.000 \\
17.000 & 6 & 0,09 & 1.500 & 102.000 \\
17.500 & 2 & 0,03 & 515 & 35.000 \\
18.000 & 7 & 0,1 & 1.853 & 126.000 \\
20.000 & 20 & 0,29 & 5.882 & 400.000 \\
21.000 & 1 & 0,01 & 309 & 21.000 \\
22.000 & 1 & 0,01 & 324 & 22.000 \\
25.000 & 5 & 0,07 & 1.838 & 125.000 \\
28.000 & 1 & 0,01 & 412 & 28.000 \\
30.000 & 2 & 0,03 & 882 & 60.000 \\
\hline Total & $\mathbf{6 8}$ & $\mathbf{1 , 0 0}$ & $\mathbf{1 8 . 3 4 6}$ & $\mathbf{1 . 2 4 7 . 5 0 0}$ \\
\hline Sumber: Analisis Data Primer, 2020 & &
\end{tabular}

Sumber : Analisis Data Primer, 2020
Hasil penelitian mengemukakan bahwa nilai terendah yang bersedia dibayarkan oleh responden beras organik di Kabupaten Banyumas sebesar Rp 12.000 per kilogramnya sedangkan nilai tertinggi adalah Rp 30.000 per kilogram. Mayoritas responden bersedia membayar beras organik pada harga Rp 20.000 per kilogram.

\section{Nilai rataan WTP}

Dugaan nilai rataan WTP beras organik di Kabupaten Banyumas didapatkan dari nilai WTP yang diberikan responden. Hasil nilai rataan WTP beras organik di Kabupaten Banyumas yang dapat dilihat pada Tabel 6 adalah Rp 18.346 per kilogram. Nilai ini lebih tinggi dibandingkan harga beras organik saat ini yaitu Rp 15.250 per kilogram.

\section{Kurva Lelang (Bid Curve)}

Kurva lelang (Bid Curve) WTP diperoleh dari frekuensi kumulatif responden terhadap nilai maksimum kesediaan membayar beras organik yang dijelaskan pada Gambar 2.

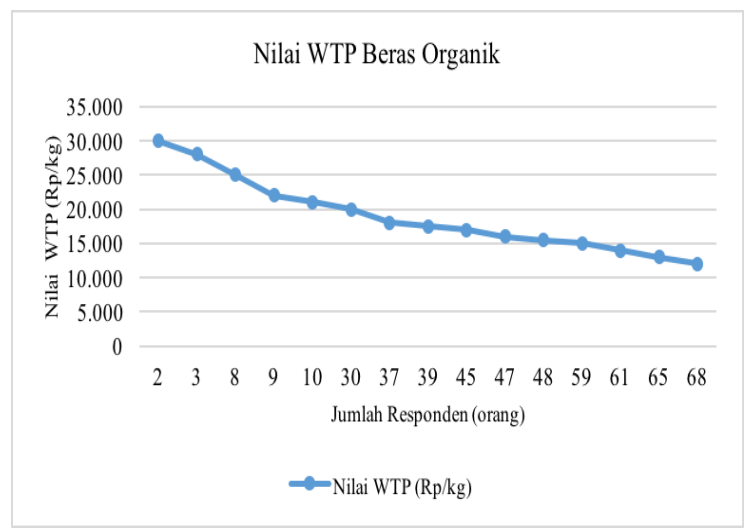

Gambar 2. Kurva WTP Beras Organik

Gambar 2 menggambarkan hubungan antara nilai willingness to pay yang bersedia dibayarkan oleh responden dengan jumlah responden yang bersedia membayar pada nilai willingness to pay tersebut. Kurva menunjukan slope negatif, hal ini berarti makin tinggi nilai willingness to pay akan semakin sedikit konsumen yang bersedia membayar.

\section{Agregat Data (Total Willingness to Pay)}

Tahapan selanjutnya yaitu menggabungkan nilai rataan lelang. Pada tahapan ini data rataan 
sampel dikonversi ke rataan populasi yaitu dengan cara rataan sampel dikali dengan jumlah responden. Berdasarkan Tabel 6, nilai rataan (mean) sebesar Rp 18.346 selanjutnya nilai rataan dikali dengan jumlah responden sebanyak 68 orang hasilnya Total WTP adalah Rp 1.247.500.

\section{FAKTOR-FAKTOR YANG MEMPENGARUHI KESEDIAAN MEMBAYAR (WILLINGNESS TO PAY) BERAS ORGANIK DI KABUPATEN BANYUMAS}

Faktor-faktor yang diduga mempengaruhi kesediaan konsumen membayar beras organik di Kabupaten Banyumas dianalisis menggunakan Analisis Regresi Logistik Biner. Pada analisis ini variabel dependen adalah kesediaan membayar beras organik, sedangkan variabel independen yang masuk ke dalam analisis regresi logistik adalah usia, pendidikan, pekerjaan, pendapatan, jumlah anggota keluarga, lama mengonsumsi, jumlah konsumsi dan persepsi konsumen terhadap kualitas beras organik.

Uji kesesuaian model regresi logistik dilakukan sebelum uji hipotesis. Model yang digunakan harus memenuhi Goodness of Fit atau harus layak. Uji kesesuaian model menggunakan Uji Hosmer dan Lemeshow untuk melihat kesesuaian model dengan data, nilai observasi yang diperoleh sama atau mendekati dengan yang diharapkan pada model. Berdasarkan hasil pengujian diperoleh nilai $H$-L Statistic 1,1644 lebih besar dari pada taraf signifikansi (alpha $=0.05$ ), artinya $\mathrm{H}_{0}$ diterima sehingga model mampu menjelaskan nilai observasinya dan model ini layak digunakan untuk memprediksi besarnya peluang WTP.

Uji Statistik G atau Likelihood Ratio Test digunakan untuk mengetahui pengaruh variabel bebas terhadap variabel terikat secara serempak pada regresi logistik. Berdasarkan hasil analisis pada Lampiran 1 diperoleh nilai signifikansi model Prob (LR Statistic) 0,00000 lebih kecil dari taraf signifikansi (alpha $=0.05$ ) yaitu 0,00000 $\leq$ 0,05 maka $\mathrm{H}_{0}$ ditolak, yang berarti minimal ada satu variabel bebas yang berpengaruh signifikan terhadap variabel terikat (WTP). Hasil output nilai MCFadden R-Squared adalah 0,6740 yang berarti variabilitas variabel bebas yang dapat dijelaskan oleh variabilitas variabel terikat sebesar 67,40 persen sisanya sebesar 32,60 persen dipengaruhi oleh faktor-faktor di luar pengujian model.

Selanjutnya akan dikaji faktor-faktor yang secara parsial mempengaruhi kesediaan konsumen untuk membayar lebih beras organik. Uji parsial dilakukan pada semua variabel bebas. Hasil pengujian dengan analisis regresi logistik ditunjukan pada Tabel 7.

Hasil uji secara parsial terhadap willingness to pay beras organik yang dilakukan menunjukkan terdapat tiga variabel independen yang berpengaruh nyata terhadap kesediaan membayar lebih beras organik pada tingkat kepercayaan 95

Tabel 7. Hasil Analisis Regresi Logistik Biner WTP Beras Organik

\begin{tabular}{lrrrc}
\hline \multicolumn{1}{c}{ Variabel } & Koefisien & Std. Error & Odds Ratio & Prob. \\
\hline C & $-16,4047$ & 7,1278 & 0,0000 & 0,0214 \\
Usia $\left(X_{1}\right)$ & 0,0333 & 0,0520 & 1,0339 & 0,5216 \\
Pendidikan $\left(X_{2}\right)$ & 0,5643 & 0,7269 & 1,7582 & 0,4376 \\
Pekerjaan $\left(X_{3}\right)$ & $-0,1299$ & 0,6290 & 0,8782 & 0,8364 \\
& & & & 0,0257 \\
Pendapatan $\left(X_{4}\right)$ & 1,2561 & 0,5629 & 3,5116 & $*$ \\
Jumlah anggota keluarga $\left(X_{5}\right)$ & 0,8107 & 0,6474 & 2,2496 & 0,2105 \\
Lama mengonsumsi $\left(X_{6}\right)$ & 2,7683 & 1,0268 & 15,9322 & $0,0070^{*}$ \\
Jumlah konsumsi $\left(X_{7}\right)$ & $-0,0774$ & 0,0986 & 0,9255 & 0,4323 \\
Persepsi kualitas beras organik $\left(X_{8}\right)$ & 4,1190 & 2,0188 & 61,4977 & $0,0413^{*}$ \\
\hline
\end{tabular}

Keterangan :

$* p<0,05$

Hasil estimasi regresi logistik pada penelitian ini :

$\ln \left[\frac{p}{1-p}\right]=-16,4047+1,2561 \mathrm{X}_{4}+2,7683 \mathrm{X}_{6}+4,1190 \mathrm{X}_{8}+\mathrm{e}$ 
persen yaitu pendapatan, lama mengonsumsi dan persepsi konsumen terhadap kualitas beras organik, sedangkan usia, pendidikan, pekerjaan, jumlah anggota keluarga dan jumlah konsumsi tidak berpengaruh nyata.

Hasil pengujian terhadap variabel usia menunjukkan bahwa nilai signifikansinya sebesar 0,5216 lebih besar dari 0,05 yang artinya usia tidak berpengaruh signifikan pada kesediaan konsumen membayar lebih beras organik. Hasil penelitian tidak mengonfirmasi hipotesis usia berpengaruh positif dan signifikan pada kesediaan membayar karena responden pada penelitian ini terdiri dari berbagai kelompok usia yang sudah menyadari akan manfaat beras organik bagi kesehatan. Beberapa konsumen mengonsumsi nasi yang dihasilkan dari beras organik karena sudah terbiasa sejak masih tinggal bersama orang tua, dan kebiasaan tersebut masih tetap diteruskan ketika sudah hidup mandiri dan tidak tinggal bersama orang tua. Hal ini mengonfirmasi pendapat (Riana et al., 2019), (Aufanada et al., 2017) yang mengemukakan usia bukan merupakan faktor penting yang mempengaruhi konsumen terhadap kesediaan membayar lebih untuk produk organik.

Nilai signifikansi pendidikan menunjukkan 0,4376 lebih besar dari 0,05 yang artinya pendidikan tidak berpengaruh signifikan pada kesediaan konsumen membayar lebih beras organik. Hal ini tidak mengonfirmasi hipotesis bahwa pendidikan berpengaruh positif dan signifikan pada kesediaan membayar beras organik. Meskipun mayoritas pendidikan konsumen beras organik di Kabupaten Banyumas adalah Sarjana, namun kesediaan membayar lebih beras organik tidak tergantung dari tingkat pendidikan. Sebanyak 23,53 persen konsumen dengan tingkat pendidikan SMP, SMA dan Diploma juga bersedia membayar lebih beras organik. Semua responden pada berbagai tingkat pendidikan mendapatkan informasi yang sama mengenai manfaat dan keunggulan beras organik, karena saat ini berbagai informasi lebih mudah diakses terutama informasi melalui internet. Pengalaman yang dirasakan pada saat mengonsumsi beras organik lebih memberikan pengaruh terhadap kesediaan konsumen membayar lebih beras organik. Hasil ini sesuai dengan pendapat
Abdillah (2014), Riana et al. (2019) yang menyatakan tinggi rendahnya tingkat pendidikan tidak berpengaruh pada kesediaan konsumen membayar lebih beras organik.

Nilai signifikansi untuk variabel pekerjaan adalah 0,8364 lebih besar dari 0,05 yang artinya hasil penelitian tidak mengonfirmasi hipotesis bahwa pekerjaan berpengaruh positif dan signifikan pada kesediaan membayar beras organik. Konsumen beras organik dalam penelitian ini didominasi oleh PNS (45,59 persen), meskipun memiliki latar belakang pekerjaan yang sama tetapi memiliki pendapatan yang berbeda tergantung dari jabatan dan golongan kepangkatan. Hal ini sesuai pendapat Abdillah (2014) yang menjelaskan pekerjaan tidak berpengaruh terhadap konsumen dalam menentukan nilai kesediaan membayar, karena meskipun kategori pekerjaannya sama namun pendapatannya bisa berbeda tergantung jabatan dan golongannya.

Pada variabel pendapatan hasil analisis menunjukkan nilai signifikansinya (Prob) sebesar 0,0257 dan nilai koefisien 1,2561. Nilai 0,0257 lebih kecil dari 0,05 yang berarti pendapatan dengan hubungan positif mempengaruhi kesediaan konsumen membayar lebih beras organik secara signifikan pada tingkat kepercayaan 95 persen. Hasil tersebut mengonfirmasi hipotesis bahwa pendapatan dengan hubungan positif berpengaruh signifikan pada kesediaan membayar beras organik. Hubungan positif berarti konsumen yang pendapatannya lebih tinggi mempunyai peluang lebih tinggi dalam kesediaan membayar beras organik. Hal ini karena harga beras organik lebih mahal dibanding dengan beras non organik. Apabila dilihat dari nilai Odd Ratio sebesar 3,5116 konsumen yang tingkat pendapatan per bulannya lebih tinggi mempunyai peluang 3,5116 kali lebih besar dalam kesediaannya membayar beras organik dibanding dengan konsumen yang pendapatannya yang lebih rendah. Konsumen dengan pendapatan lebih tinggi akan cenderung lebih memperhatikan kualitas bahan makanan yang dikonsumsinya karena lebih mampu dalam memenuhi kebutuhan yang lebih baik. Hal tersebut sesuai dengan pendapat Yu et al. (2014), Aufanada et al. (2017), Fathia et al. (2018) yang menjelaskan bahwa makin tinggi tingkat pendapatan konsumen, maka 
makin besar kesediaan membayar produk organik. Pendapatan memiliki pengaruh terhadap tingkat konsumsi, pendapatan yang semakin besar akan mempengaruhi selera mereka yang pada akhirnya akan mempengaruhi peningkatan barang yang dikonsumsi baik kuantitas maupun kualitas barang tersebut (Soekartawi, 2010).

Hasil pengujian variabel jumlah anggota keluarga nilai signifikansinya 0,2105 lebih besar dari 0,05 , yang artinya nilai tersebut tidak mengonfirmasi hipotesis bahwa jumlah anggota keluarga berpengaruh negatif dan signifikan terhadap kesediaan membayar beras organik. Pada penelitian ini mayoritas konsumen beras organik adalah keluarga kecil yang jumlah anggota keluarganya satu hingga empat orang. Namun jumlah anggota keluarga yang lebih sedikit tidak selalu menjamin kesediaan membayar lebih beras organik. Hal ini dapat disebabkan karena jumlah pendapatan keluarga kecil tidak selalu lebih besar dari konsumen yang memiliki keluarga sedang atau besar. Hasil penelitian ini mengonfirmasi penelitian Yuningsih (2016), Aufanada et al. (2017), Riana et al. (2019) yang menjelaskan bahwa jumlah anggota keluarga dan keberadaan anak tidak berpengaruh pada kesediaan membayar premium untuk memperoleh produk pangan organik.

Lama mengonsumsi mempengaruhi kesediaan konsumen membayar lebih beras organik secara signifikan dengan hubungan positif. Hal tersebut dapat dilihat dari nilai signifikansinya (Prob) yaitu 0,0070 lebih kecil dari 0,05 dan nilai koefisiennya 2,7683 . Hasil penelitian ini mengonfirmasi hipotesis bahwa lama mengonsumsi berpengaruh positif dan signifikan terhadap kesediaan membayar beras organik. Nilai Odds Ratio variabel lama mengonsumsi adalah 15,9322 yang berarti bahwa responden yang mengonsumsi beras organik lebih lama memiliki peluang 15,9322 kali lebih tinggi terhadap kesediaan membayar beras organik. Lama konsumsi berhubungan dengan persepsi konsumen terhadap kualitas beras organik. Sunyoto (2014) menyatakan bahwa persepsi dapat melibatkan penafsiran seseorang terhadap suatu kejadian berdasar pengalaman masa lalu. Pengalaman langsung dengan objek dapat membentuk sikap (Sumarwan et al., 2012). Sikap yang berdasar pengalaman langsung membuat kepercayaan pada suatu produk semakin besar. Sikap dan keyakinan adalah daya yang kuat dan secara langsung mempengaruhi persepsi dan perilaku konsumen (Sangadji dan Sopiah, 2013). Semakin lama konsumen mengonsumsi beras organik, konsumen akan semakin merasakan manfaat beras organik bagi kesehatan dan makin bisa membedakan rasa beras organik dibandingkan dengan beras non organik. Hal tersebut mendukung pendapat Fathia et al., (2018) yang mengemukakan bahwa kebiasaan dapat menentukan sikap konsumen terhadap suatu produk. Keyakinan dan sikap konsumen yang mengonsumsi beras organik setiap hari lebih memilih beras organik daripada beras non organik.

Nilai signifikansi jumlah konsumsi beras organik adalah 0,4323 lebih besar dari 0,05, yang berarti jumlah konsumsi beras organik tidak berpengaruh signifikan pada kesediaan konsumen membayar lebih beras organik, sehingga hasil penelitian tidak mengonfirmasi hipotesis bahwa jumlah konsumsi beras organik berpengaruh negatif dan signifikan terhadap kesediaan membayar beras organik. Mayoritas responden beras organik tingkat pendapatannya lebih dari $\mathrm{Rp}$ 3.000.000 yaitu sebanyak 76,48 persen responden. Konsumen yang memiliki pendapatan yang tinggi cenderung menginginkan peningkatan kualitas dan kuantitas bahan pangan khususnya beras. Hal ini mengonfirmasi pendapat Nasution (2016) yang menyatakan bahwa gaya hidup masyarakat kelas menengah mendorong volume dan pola konsumsi pangan, karena pada umumnya pendapatan mereka cukup besar.

Persepsi konsumen terhadap kualitas beras organik berpengaruh signifikan terhadap kesediaan membayar lebih beras organik, karena nilai signifikansinya yaitu 0,0413 lebih kecil dari 0,05 dengan nilai koefisiennya 4,1190 dan odd ratio 61,4977 . Hal ini berarti konsumen yang memiliki persepsi bahwa beras organik memiliki kualitas tinggi memiliki peluang kesediaan membayar beras lebih organik sebanyak 61,4977 kali lebih besar daripada konsumen yang memiliki persepsi bahwa kualitas beras organik rendah. Mayoritas konsumen merasakan kualitas yang baik dari beras organik yang dikonsumsinya, sehingga konsumen tersebut bersedia membayar lebih mahal 
dari beras non organik. Penilaian kualitas produk dipengaruhi dari pengetahuan dan pengalaman tiap individu, sehingga konsumen mempunyai persepsi serta penilaian yang berbeda terhadap produk organik. Konsumen yang semakin mengerti dan merasakan kualitas dan manfaat beras organik akan semakin tertarik untuk membeli serta mengonsumsi beras organik. Hasil tersebut mengonfirmasi pendapat Aufanada et al. (2017) yang menyatakan konsumen bersedia membayar lebih produk organik karena kualitas serta manfaat yang dirasakan dari mengonsumsi produk organik tersebut. Konsumen yang menjadikan kualitas dan manfaat bagi kesehatan sebagai pertimbangan dalam memilih produk pangan akan tetap bersedia membayar walaupun terjadi peningkatan harga.. Konsumen berharap suatu produk dapat berfungsi dengan baik (performance expectation) dan menjadikan harapan tersebut sebagai standar kualitas, kemudian konsumen membandingkan harapannya tersebut dengan fungsi dan kualitas yang sesungguhnya dari penggunaan produk tersebut (actual performance) yang sebenarnya adalah persepsi konsumen (Sangadji dan Sopiah, 2013).

Nilai persentase akurasi prediksi (percently correctly predicted) digunakan untuk mengetahui seberapa besar ketepatan model diskriminan yang terbentuk dalam memprediksi atau mengelompokkan konsumen ke dalam suatu kategori. Semakin tinggi persentase prediksi menunjukan bahwa model makin baik. Hasil analisis pada Lampiran 2, menunjukan nilai persentase akurasi prediksi sebesar 92,65 persen sehingga dapat disimpulkan model cukup baik untuk memprediksi kelompok yang bersedia dan tidak bersedia membayar lebih beras organik.

\section{SIMPULAN DAN SARAN}

\section{SIMPULAN}

Simpulan dari hasil penelitian yaitu sebagai berikut:

1. Karakteristik konsumen yang bersedia membayar lebih beras organik di Kabupaten Banyumas di dominasi oleh konsumen dengan usia produktif, dengan latar belakang pendidikan tinggi, sudah berkeluarga dan memiliki pendapatan cukup sehingga lebih selektif dalam pemilihan beras organik dan memiliki kesadaran akan manfaat beras organik bagi kesehatan.

2. Harga maksimal beras organik yang bersedia dibayarkan oleh konsumen di Kabupaten Banyumas adalah Rp 18.346,00 per kilogram. Nilai tersebut lebih tinggi dibandingkan ratarata harga beras organik di Banyumas yaitu Rp 15.250,00 per kilogram.

3. Semakin tinggi pendapatan maka konsumen akan cenderung terus mengonsumsi beras organik. Semakin lama pengalaman konsumen mengonsumsi beras organik maka akan semakin memahami dan merasakan manfaatnya. Semakin baik persepsi konsumen terhadap kualitas beras organik maka konsumen akan mempertahankan konsumsi beras organik.

4. Keterbatasan pada penelitian ini khususnya terkait dengan metode penarikan sampel menggunakan snowball sampling yang merupakan metode non-probabilitas sampling dimana responden dalam penelitian dipilih secara berantai, sehingga sampel sebanyak 68 konsumen yang diperoleh mungkin tidak mewakili seluruh populasi untuk penelitian ini.

\section{SARAN}

Saran yang diberikan penulis untuk penelitian ini yaitu:

1. Nilai willingness to pay beras organik dapat dijadikan acuan untuk menetapkan harga jual beras organik di Kabupaten Banyumas.

2. Petani dan pemasar hendaknya senantiasa memperhatikan kualitas beras organik, karena penilaian terhadap kualitas beras organik memberikan pengaruh terhadap kesediaan membayar lebih beras organik di Kabupaten Banyumas.

3. Untuk penelitian selanjutnya, peneliti dapat menambahkan jumlah responden dan memilih metode penggambilan data yang lebih baik agar potensi bias tersebut dapat dikurangi dan generalisasi hasil lebih luas.

\section{DAFTAR PUSTAKA}

Akamin A, Bidogeza JC, N JRM, Afari SV. 2017. Abdillah, R.F. 2014. Analisis Kesediaan Membayar (Willingness to Pay) Produk Healthy Food Beras Merah Pulen di Serambi 
Botani, Botani Square, Bogor. [Skripsi]. Bogor: Institut Pertanian Bogor.

Aufanada, V., T. Ekowati dan W.D. Prastiwi. 2017. Kesediaan Membayar Produk Sayuran Organik di Pasar Modern Jakarta Selatan. AGRARIS: Journal of Agribusiness and Rural Development Research Vol. 3 No. 2: 67-75. https://doi.org/10.18196/agr.3246.

Celona, Natasya. 2015. Analisis Kesediaan Membayar Konsumen Beberapa Komoditi Sayuran Organik (Studi Kasus: Giant Hypermarket, Botani Square, Kota Bogor). [Skripsi]. Bogor: Institut Pertanian Bogor.

Fathia, Q.N., R. Nurmalina dan M. Simanjuntak. 2018. Consumer's Attitude and Willingness to Pay for Organic Rice. Indonesian Journal of Business and Entrepreneurship Vol. 4 No. 1: 11-21. https://doi.org/10.17358/ijbe.4.1.11.

Fauzi, Akhmad. 2004. Ekonomi Sumber Daya Alam dan Lingkungan Teori dan Aplikasi. Jakarta: PT. Gramedia Pustaka Utama.

Gil, J.M., A. Gracia and M. Sánchez. 2000. Market Segmentation and Willingness to Pay Organic Product in Spain. International Food and Agribusiness Management Review 3 (2000): 207-226. https://doi.org/10.1016/S10967508(01)0 0040-4.

Hanis, I.A., Jinap, S., Nasir, S.M., Alias, R. and Shahrim, A.K. 2012. Consumers' Demand and Willingness to Pay for Rice Attributes in Malaysia. International Food Research Journal 19 (1): 363-369.

Krystallis, A. and G. Chryssohoidis. 2005. Consumers' Willingness to Pay for Organic Food : Factors that Affect it and Variation per Organic Product Type. British Food Journal, 107 (5): 320-343.

Mowen J.C and Minor M. 2002. Perilaku Konsumen Jilid 1 Edisi Kelima Alih Bahasa Lina Salim. Jakarta: Penerbit Erlangga.

Nasution, M.P. 2016. Analisis Faktor yang Mempengaruhi Willingness to Pay Beras di Kota Medan. [Thesis]. Medan: Universitas Sumatera Utara.

Purwasasmita, M. dan A. Sutaryat. 2014. Padi SRI Organik Indonesia (Edisi Revisi). Jakarta: Penebar Swadaya.
Rahayu, A.D., T.D. Hapsari dan J. Adam. 2017. Analisis Kesediaan Membayar (Willingness to Pay) Beras Cerdas CV An-Nahlah di Kabupaten Jember. JSEP Vol 10 No. 1 : 17-29. https://doi.org/10.19184/ jsep.v10i1.5211.

Riana, E.T., Mukson dan W. Roessali. 2019. Analisis Kesediaan Membayar (Willingness to Pay) Konsumen Terhadap Berbagai Jenis Beras Organik di Kota Semarang (Kasus di Pasar Modern Gelael Signature). Jurnal Ekonomi Pertanian dan Agribisnis (JEPA) Vol 3, No 4: 689-700.

https://doi.org/10.21776/ub.jepa.2019.003. 04.4 .

Rusma, J., M. Hubeis dan B. Suharjo. 2011. Kajian Preferensi Konsumen Rumah Tangga Terhadap Beras Organik di Wilayah Kota Bogor. Manajemen IKM. Vol 6 (1): 49-45. https://doi.org/10. 29244/mikm.6.1.49-54.

Sangadji E.M. dan Sopiah. 2013. Perilaku Konsumen Pendekatan Praktis Disertai Himpunan Jurnal Penelitian. Yogyakarta: Penerbit Andi.

Setiyadi, H., S. Hartono dan D.H. Darwanto. 2016. Consumer Willingness to Pay of Organic Rice and The Factors which Affected in Pontianak. Ilmu Pertanian (Agricultural Science) Vol 1 No 3: 130-136. https://doi.org/10.22146/ipas.11227.

Sulistyana, P, Mulyo J.H dan Jamhari. 2014. Konsumsi Beras Organik Pada Tingkat Rumah Tangga di Kota Yogyakarta. Jurnal Agro Ekonomi Vol. 24 No.1 Juni 2014: 25-34. https://doi.org/10.22146/ agroekonomi.17357

Soekartawi. 2010. Agribisnis Teori dan Aplikasinya. Jakarta: PT Raja Grafindo Persada.

Sumarwan, U., A.G Prihartono, A.W. Sumarlin, D.A Mamahit, E. Purnomohadi, J. Hasan, M. Ahmady, R. Wulandari, T. Haryono. 2012. Riset Pemasaran dan Konsumen Seri 2: Pengolahan dan Analisis Data Serta Kajian Budaya dan Risiko Kredit, Marketing Destination Brands, Brands Equity dan Motivasi, Model Keputusan Konsumen, Sikap Konsumen dan Produk Hijau, Pemasaran Hubungan, Consumer Awarness dan 
Sertifikasi Ekolabel, Model Pengembangan Kota Gas. Bogor: PT Penerbit IPB Press.

Sumarwan, U., A. Jauzi, A. Mulyana, B.N. Karno, P.K. Mawardi dan W. Nugroho. 2013a. Riset Pemasaran dan Konsumen Seri 1: Paduan Riset dan Kajian: Kepuasan, Perilaku Pembelian, Gaya Hidup, Loyalitas dan Persepsi Risiko. Bogor: PT Penerbit IPB Press.

Sumarwan, U., A. Noviandi dan Kirbrandoko. 2013b. Analisis Proses Keputusan Pembelian, Persepsi dan Sikap Konsumen Terhadap Beras Organik di Jabotabek. Artikel PANGAN Vol. 22 No. 2:333-344. https://doi.org/10.33964/jp.v 22i2.

Sunyoto, D. 2014. Praktik Riset Perilaku Konsumen Teori, Kuesioner, Alat, dan Analisis Data. Yogyakarta: CAPS (Center of Academic Publishing Service).

Yu, Xiaohua., Z. Gao and Y. Zeng. 2014. Willingness to Pay for The "Green Food" in China. Food Policy 45: 80-87. http://dx.doi.org/10.1016/j.foodpol.2014.0 1.003.

Yuningsih, Lisda. 2016. Analisis Willingness to Pay Beras Pandan Wangi Organik. [Skripsi]. Bogor: Institut Pertanian Bogor. 